\title{
Effects of Usag-1 and Bmp7 deficiencies on murine tooth morphogenesis
}

\author{
Kazuyuki Saito ${ }^{1 *}$, Katsu Takahashi ${ }^{1}$, Masakazu Asahara², Honoka Kiso ${ }^{1}$, Yumiko Togo ${ }^{1}$, Hiroko Tsukamoto ${ }^{1}$, \\ Boyen Huang ${ }^{3}$, Manabu Sugai ${ }^{4}$, Akira Shimizu ${ }^{5}$, Masaharu Motokawa ${ }^{6}$, Harold C. Slavkin ${ }^{7}$ and Kazuhisa Bessho ${ }^{1}$
}

\begin{abstract}
Background: Wnt5a and Mrfzb1 genes are involved in the regulation of tooth size, and their expression levels are similar to that of Bmp7 during morphogenesis, including during the cap and early bell stages of tooth formation. We previously reported that Usag-1-deficient mice form supernumerary maxillary incisors. Thus, we hypothesized that BMP7 and USAG-1 signaling molecules may play important roles in tooth morphogenesis. In this study, we established double genetically modified mice to examine the in vivo inter-relationships between Bmp7 and Usag-1.

Results: We measured the volume and cross-sectional areas of the mandibular incisors using micro-computed tomography (micro-CT) in adult Bmp7- and Usag-7-LacZ knock-in mice and their $\mathrm{F}_{2}$ generation upon interbreeding. The mandibular incisors of adult Bmp7+/- mice were significantly larger than those of wild-type (WT) mice. The mandibular incisors of adult Usag-1-/- mice were the largest of all genotypes examined. In the $F_{2}$ generation, the effects of these genes were additive; $B m p 7+/-$ was most strongly associated with the increase in tooth size using generalized linear models, and the total area of mandibular supernumerary incisors of Usag-1-/-Bmp7+/- mice was significantly larger than that of Usag-1-/-Bmp7 +/+ mice. At embryonic day 15 (E15), BrdU assays demonstrated that the labeling index of Bmp7+/- embryos was significantly higher than that of WT embryos in the cervical loop. Additionally, the labeling index of Usag-1-/- embryos was significantly the highest of all genotypes examined in dental papilla.
\end{abstract}

Conclusions: Bmp7 heterozygous mice exhibited significantly increased tooth sizes, suggesting that tooth size was controlled by specific gene expression. Our findings may be useful in applications of regenerative medicine and dentistry.

Keywords: Tooth size, Bmp7, Usag-1, Mouse model, Tooth volume, Tooth morphogenesis

\section{Background}

Development of the dentition is regulated by time- and position-specific reciprocal epithelial-mesenchymal interactions [1-4]. These odontogenic interactions are directed and coordinated by transcription factors, growth and signaling factors, their cognate receptors, and extracellular matrix constituents [5]. Collectively, various combinations of molecules within these interactions determine when or where teeth develop and modulate the specifications for tooth size and shape.

Noggin, Wnt5a, and Mfrzb1 genes have been shown to regulate tooth size [6-9]. Cai et al., using hetero-specific

\footnotetext{
* Correspondence: kazuyuki@kuhp.kyoto-u.ac.jp

${ }^{1}$ Department of Oral and Maxillofacial Surgery, Graduate School of Medicine, Kyoto University, Shogoin-Kawahara-cho 54, Sakyo-ku, Kyoto 606-8397, Japan Full list of author information is available at the end of the article
}

tissue recombination from rat molar tooth organs, demonstrated that tooth size is determined not by dental papilla mesenchymal cell number, but by intrinsic tissuespecific dental papilla mesenchymal factors [10]. In addition, exogenous treatment with bone morphogenic protein (BMP) 4, Noggin, fibroblast growth factor (FGF) 3 , and FGF10 does not affect tooth size, despite the observation that BMP2/4, FGF3/10, LEF1, and WNT5a/5b are expressed in the dental mesenchyme during the cap and early bell stages of tooth morphogenesis [6, 11-15]. The crown width of a bioengineered molar reconstructed with dissociated epithelial and mesenchymal cells through the organ germ method is correlated with the length of the contact area between the epithelial and mesenchymal cell layers [16]. 
In conditional Bmp7-deficient embryos, the maxillary incisor tooth organs are either missing or hypoplastic, and the development of the first molar tooth organs is delayed, malformed, or missing [17]. Therefore, $B m p 7$ is assumed to be an essential growth factor for tooth morphogenesis. BMP7 is a $35-\mathrm{kDa}$ homodimeric protein that is associated with a variety of signaling pathways, including the canonical SMAD pathway, mitogen-activated protein kinase (MAPK)-related pathways, and the phosphoinositol 3-kinase (PI3K)/Akt pathway [18-21]. Uterine sensitization-associated gene-1 (USAG-1; also known as sclerostin domain-containing protein 1 [SOSTDC1], ectodin, and Wise) is a heavily glycosylated $28-30 \mathrm{kDa}$ secretory protein that functions as a monomer to induce signal transduction. USAG-1 binds to the Wnt coreceptors low-density lipoprotein receptor-related protein (LRP) 5 and LRP6 and inhibits Wnt signaling [22, 23]. LRP4 modulates and integrates BMP and canonical Wnt signaling during tooth morphogenesis by binding to secreted USAG-1 [24]. USAG-1 expression is further restricted to the distal renal tubules, in a pattern similar to the localization of BMP7. USAG-1 is a BMP antagonist; it interacts with BMP7 in the developing and adult kidney and directly binds to BMP2/4/7, as assayed using co-immunoprecipitation studies [25]. Moreover, we previously reported that $U$ sag-1-deficient mice exhibit supernumerary maxillary incisors in response to enhanced BMP signaling and that BMP signaling is modulated by Wnt signaling in Usag-1-deficient mice [26, 27].

Based on these observations and findings, we hypothesized that BMP7 and USAG-1 play important roles in tooth morphogenesis. Therefore, we previously established double genetically modified mice to analyze the in vivo inter-relationships between BMP7 and USAG-1. Using this model, we demonstrated that USAG-1 inhibits BMP7 signaling, leading to apoptosis and degeneration of rudimentary tooth germs in maxillary supernumerary incisor formation [28]. Moreover, we found that the tooth size in mandibular incisors of $B m p 7$ heterozygous mice was altered. Accordingly, in this study, we examined the effects of BMP7 and USAG-1 signaling on tooth size in mandibular incisors using the $F_{2}$ generation of mice.

\section{Methods}

\section{Production and analysis of Usag-1- and Bmp7-LacZ knock-in mice}

Bmp7-LacZ knock-in (ICR) mice and Usag1-LacZ knock-in $(\mathrm{C} 57 \mathrm{BL} / 6)$ mice were produced as previously described [29, 30]. Bmp7-deficient mice were embryonic lethal. Day E0 was established as midnight prior to finding a vaginal plug.

Polymerase chain reaction (PCR) amplification was performed using KOD FX NEO polymerase (TOYOBO, Osaka, Japan) and specific primers for genotyping.

\section{X-gal staining}

The bacterial LacZ ( $\beta$-galactosidase) gene in Bmp LacZ/ LacZ (ICR) and Usag1LacZ/LacZ (C57BL/6) mice was knocked into the gene of interest $[29,30]$. Frozen sections of embryos were fixed in $4 \%$ paraformaldehyde for 2 min and stained with X-Gal (Wako) twice as whole mounts and frozen sections, followed by counterstaining with Nuclear Fast Red (Kernechtrot). For X-gal staining, embryos were incubated at $37{ }^{\circ} \mathrm{C}$ in buffer $(20 \mathrm{mg} / \mathrm{mL}$ $\mathrm{X}$-gal/dimethylformamide, $35 \mathrm{mM} \mathrm{K} \mathrm{K}_{3} \mathrm{Fe}(\mathrm{CN})_{6}, 35 \mathrm{mM}$ $\mathrm{K}_{4} \mathrm{Fe}(\mathrm{CN})_{6}, 2 \mathrm{mM} \mathrm{MgCl}, 0.02 \% \mathrm{NP}-40,0.01 \%$ sodium deoxycholate, $1 \times$ phosphate-buffered saline [PBS]). We observed mandibular incisors in $B m p 7+/-$ (ICR) and Usag-1+/- (C57BL/6) mice and mandibular molars in Usag-1+/- (C57BL/6) mice at E14 and E15.

\section{Analysis of the adult tooth phenotype}

Three-dimensional (3D) computed tomography (CT) scans (SMX-100XT-SV3; Shimadzu, Kyoto, Japan) were performed using the heads of adult mice. We converted CB files to TIFF files. CB files had $512 \times$ 512 pixels, 8 bits, and a voxel size of $x: y: z=1: 1: 1$ (approximately $0.06 \mathrm{~mm}$ per side). Next, 3D images were reconstructed and analyzed with computer imaging software (INTAGE Realia and Volume Player software; KGT Inc, Tokyo, Japan) [31]. The mandibular incisor volume was measured using the imaging software; then, to measure the cross-sectional area, mandibular incisors were cut vertically to the tooth axes at the uppermost point on the incisor alveolar rim (at the bone-tooth junction), so as to avoid the influence of environmental factors, such as dental occlusion and tooth attrition. The cross-sectional area of the incisors was measured using ImageJ software. We analyzed a total of 22 wild-type (WT) and $20 \mathrm{Bmp} 7+/$ - samples in adult Bmp7-LacZ knock-in (ICR) mice at 2 months after birth, a total of 21 individual genotypes in adult Usag1LacZ knock-in $(\mathrm{C} 57 \mathrm{BL} / 6)$ mice at 3 months after birth, and nine Usag-1+/+Bmp7+/+, 12 Usag-1+/-Bmp7+/+, 18 Usag-1 $-/-B m p 7+/+, \quad 14$ Usag-1-/-Bmp7+/-, 28 Usag-1 $+/-B m p 7+/-$, and 17 Usag-1+/+Bmp $7+/-$ adult $\mathrm{F}_{2}$ generation mice at 4 months after birth. Data for volume and cross-sectional area obtained from the right and left incisors were summed.

We measured the cross-sectional area of mandibular supernumerary incisors of three Usag-1-/-Bmp $7+/+$ and six Usag-1-/-Bmp7+/- adult $\mathrm{F}_{2}$ generation mice. We used two Usag-1-/-Bmp7+/+ and six Usag-1 $-/-B m p 7+/-$ mice at 1 month after birth and one Usag-1-/-Bmp $7+/+$ mouse at 4 months after birth. The total area was measured in cases of multiple supernumerary teeth.

To evaluate the effects of $B m p 7$ and Usag- 1 on the total dentition, we also measured mandibular molars. 
We obtained photographs of mandibular three molars of the $F_{2}$ generation from directly above the occlusal view under a stereomicroscope and measured the projected area with Image J software using an image of a ruler taken at the same magnification. The distances between the lens and specimen were fixed. We examined unilateral mandibular molars from seven $U s a g-1+/+B m p 7+/+$, 16 Usag-1+/-Bmp7+/+, 16 Usag-1+/+Bmp7+/-, and 31 Usag-1+/-Bmp $7+/-$ adult $\mathrm{F}_{2}$ generation mice at 1 month after birth. Because molar form Usag-1-/- mice fused $[24,32,33]$, we did not measure these molars.

\section{BrdU immunostaining}

Cell proliferation was detected by BrdU immunostaining (BrdU Solution and BD Pharmingen BrdU In-situ Detection Kit; BD Biosciences) according to the manufacturer's specifications. We made a working solution of BrdU in PBS at $1 \mathrm{mg} / \mathrm{mL}$ and injected the mice intraperitoneally with $1 \mathrm{~mL}$ of the BrdU solution. After $2 \mathrm{~h}$, the mice were sacrificed, and the heads of the embryos were removed and fixed in $4 \%$ paraformaldehyde overnight. Paraffin sections $(7 \mu \mathrm{m})$ were then created. Background tissue was stained with hematoxylin for $5 \mathrm{~s}$. We counted approximately 500-1000 nuclei under a light microscope, and the labeling index was determined as $(\mathrm{BrdU}+$ cells/total nuclei)/100.

\section{Detection of apoptosis}

Apoptotic cells in situ were detected by the TUNEL method using an apopTag Plus In Situ Apoptosis Detection Kit-Fluorescein (Chemicon International) according to the specifications of the manufacturer.

For paraffin-embedded sections, embryos were fixed in 4 \% paraformaldehyde in PBS overnight. After fluorescent staining, the sections were counterstained with 4',6-diamidino-2-phenylindole nuclear staining (Dapi Fluoromount-G; Southern Biotech).

\section{Statistical analysis}

Data are presented as the means \pm standard deviations. Statistical significance was assessed by analysis of variance (ANOVA) with the statistical program R. Gaussian distributions were determined by the Anderson Darling normality test.

In adult Bmp7-LacZ knock-in mice, $22 \mathrm{WT}$ samples and 20 Bmp7+/- samples collected from mice at 2 months after birth were analyzed. We calculated the mean volume and area of the right and left incisors. Statistical significance was determined by unpaired onetailed t-tests for volume and by Mann-Whitney U tests for cross-sectional area.

In adult Usag1-LacZ knock-in mice, 21 samples of individual genotypes at 3 months after birth were analyzed as stated above. Statistical significance was determined using Kruskal-Wallis and Steel-Dwass tests for multiple comparisons in volume and by one-way ANOVA using a Games Howell test for multiple comparisons in crosssectional area.

In the adult $\mathrm{F}_{2}$ generation, we examined nine Usag-1 +/+Bmp7+/+, 12 Usag-1+/-Bmp7+/+, 18 Usag-1-/-Bmp7 +/+, 14 Usag-1-/-Bmp7+/-, 28 Usag-1+/-Bmp7+/-, and 17 Usag-1+/+Bmp $7+/-$ mice, as mentioned above. Statistical significance was determined by one-way ANOVA using a Games Howell test for multiple comparisons.

In the analysis of mandibular molars in the adult $F_{2}$ generation, statistical significance was determined by unpaired two-tailed t-tests (except for M1 and M2 in Usag-1 +/- mice, for which Welch's tests [M1] or Mann-Whitney U tests [M2] were used).

Finally, for analysis of cell proliferation using BrdU staining in the mandibular incisors in Bmp7-LacZ knockin mice at E15 and analysis of mandibular supernumerary incisors in the adult $F_{2}$ generation, statistical significance was determined using Mann-Whitney $U$ tests. For analysis of cell proliferation using BrdU staining in the mandibular incisors in Usag1-LacZ knock-in mice at E15, statistical significance was determined using KruskalWallis and Steel-Dwass tests for multiple comparisons.

\section{Results}

Expression of Bmp7 and Usag-1 at E14 and E15

Sections from Bmp7+/- mice indicated that Bmp7 was expressed (blue) in the mesenchyme around the tooth germ (Fig. 1a, d, g), rudimentary incisor (Fig. 1a, d), and enamel knot (Fig. 1b, e). Sections from Usag-1+/- mice indicated that Usag-1 was expressed (blue) in a small portion of the epithelia, excluding the enamel knot and mesenchyme around the tooth germ at E15, during the early bell stage (Fig. 1f, h,) (Additional file 1: Figure S1B, C).

\section{Micro-CT analysis of the mandibular incisors in adult Bmp7-LacZ knock-in mice}

The volume and cross-sectional area of the mandibular incisors were larger in $B m p 7+/-(\mathrm{ICR})$ mice than in WT mice (Fig. 2a). Volumes of Bmp7+/- mice were significantly larger than those of WT mice (Fig. 2e). The cross-sectional areas of $B m p 7+/$ - mice were significantly larger than those of WT mice (Fig. 2f).

\section{Micro-CT analysis of the mandibular incisors in adult Usag1-LacZ knock-in mice}

The volume and cross-sectional area of the mandibular incisors in Usag-1LacZ knock-in (C57BL/6) mice were larger than those in any other diplotype (Fig. 2b). The volume and cross-sectional area in Usag-1-/- mice were significantly larger than those in all other diplotype (Fig. 2e, f). The volume and cross-sectional area in 


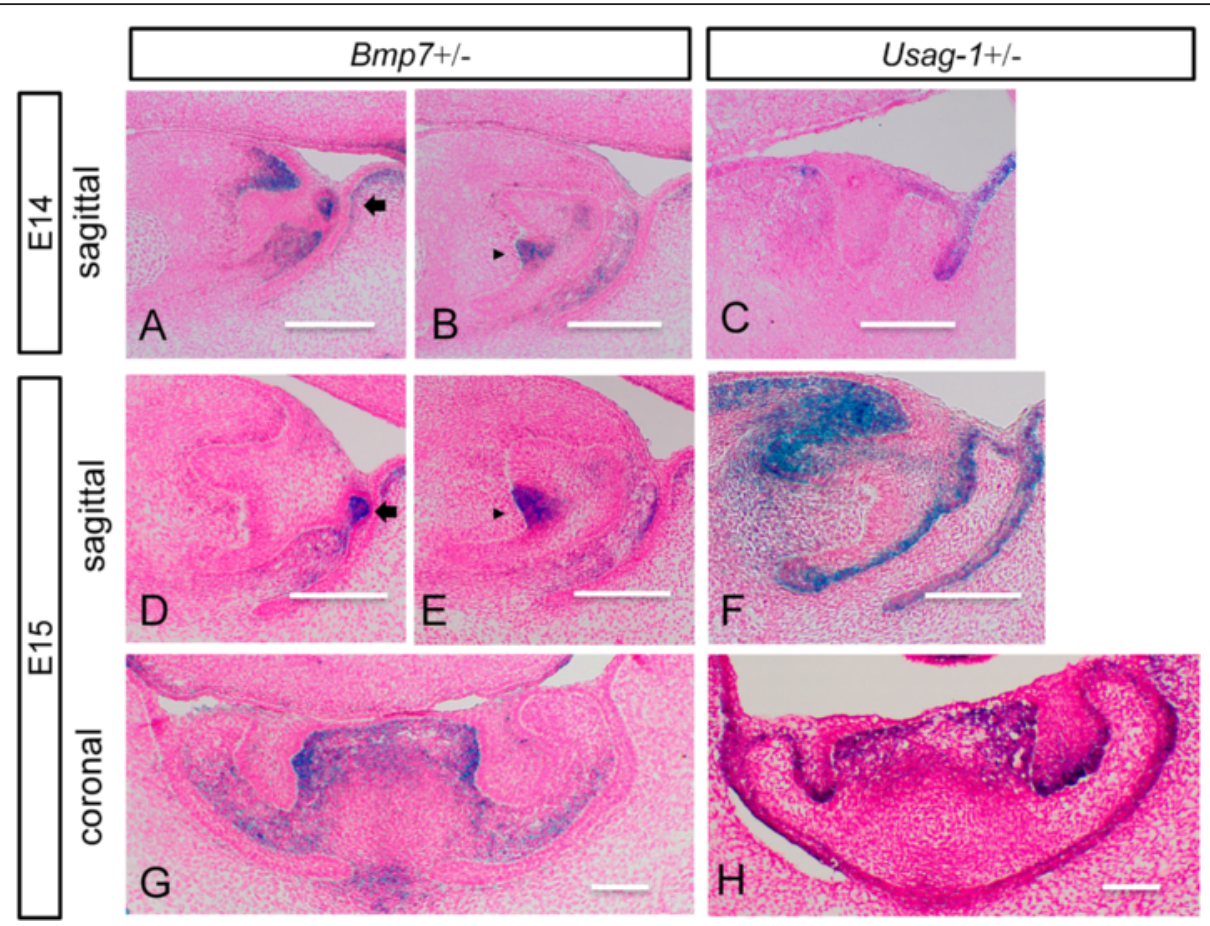

Fig. 1 X-gal staining in mandibular incisors of Bmp7+/- (ICR) and Usag-1+/- (C57BL/6) mice at E14/E15. Tissue sections from mandibular incisors of Bmp7+/- (ICR) and Usag-1+/- (C57BL/6) mice at E14 and E15 were stained with X-gal (a-h). Scale bars indicate $100 \mu \mathrm{m}$. a-f Sagittal sections. $\mathbf{g}, \mathbf{h}$ Coronal sections. $\mathbf{a}, \mathbf{b}, \mathbf{d}, \mathbf{e}, \mathbf{g}$ Embryos of Bmp7+/- (ICR) mice. Bmp7 was expressed (blue) in the mesenchyme near the tooth germ. $\mathbf{c}, \mathbf{f}, \mathbf{h}$ Embryos of Usag-1+/- (C57BL/6) mice. Usag-1 was expressed (blue) in a small portion of epithelia, except for the enamel knot and the mesenchyme near the tooth germ. a-c Embryonic day 14. d-h Embryonic day 15. a, d Sections near a rudimentary incisor (arrows) with strong expression are shown. b, e Sections near an enamel knot (arrowheads) with strong expression are shown

Usag-1+/- mice were significantly smaller than those in WT mice (Fig. 2e, f).

Few mice exhibited malocclusion among Usag-1-/mice. Mice that had malocclusion, taking into account feeding disorders and changes in tooth size, were excluded from the statistical analyses. Two of 23 Usag-1-/- mice were excluded (Additional file 2: Figure S2C),

\section{Analysis of the projected areas of the occlusal surface of mandibular molars in adult $F_{2}$ mice}

The areas of the occlusal surface of the mandibular molars in Bmp7+/- mice were significantly larger than those in WT mice for both the three individual molars and the total (Fig. 3a, b). The areas of the occlusal surface of the mandibular molars in Usag-1+/- mice were significantly smaller than those in WT mice, except for M1 (Fig. 3a, c).

We used a generalized linear model (GLM) to examine the effects of respective genes and genotypes on tooth size. The model formula of the GLM was "Tooth Size $=U$ Usag-1 + Bmp7". We did not consider interactions. From this analysis, we found that $B m p 7+/-$ was associated with an increase in tooth size, whereas Usag-1+/- was associated with a decrease in area (Table 1). The error structure of the response variable followed a
Gaussian distribution. The link function was a linear model. The explanatory variable was categorical data. We used genotypes as the categorical data.

\section{Micro-CT analysis of the mandibular incisors in the adult $F_{2}$ generation}

The volume and cross-sectional area of the mandibular incisors of Usag-1-/-Bmp $7+/-$ mice were larger than those of all other genotypes (Fig. 2c). This analysis clarified that the effects of each diplotype of $B m p 7$ and Usag- 1 were additive for volume and cross-sectional area (Fig. 2g, h).

Next, a GLM was used, as described in the Methods. Usag-1-/- and Bmp-7+/- were associated with increased tooth size, whereas Usag-1+/- was associated with decreased tooth size (Table 2). This analysis confirmed that $B m p 7+/-$ was most strongly associated with an increase in tooth size.

Two of 16 Usag-1-/-Bmp7+/- mice exhibited malocclusion was excluded (Additional file 2: Figure S2D),

\section{Analysis of cell proliferation using BrdU staining of the mandibular incisors at E15}

In murine incisors and molars, tooth eruption and tooth root formation are completed by about P20 or P21. The 


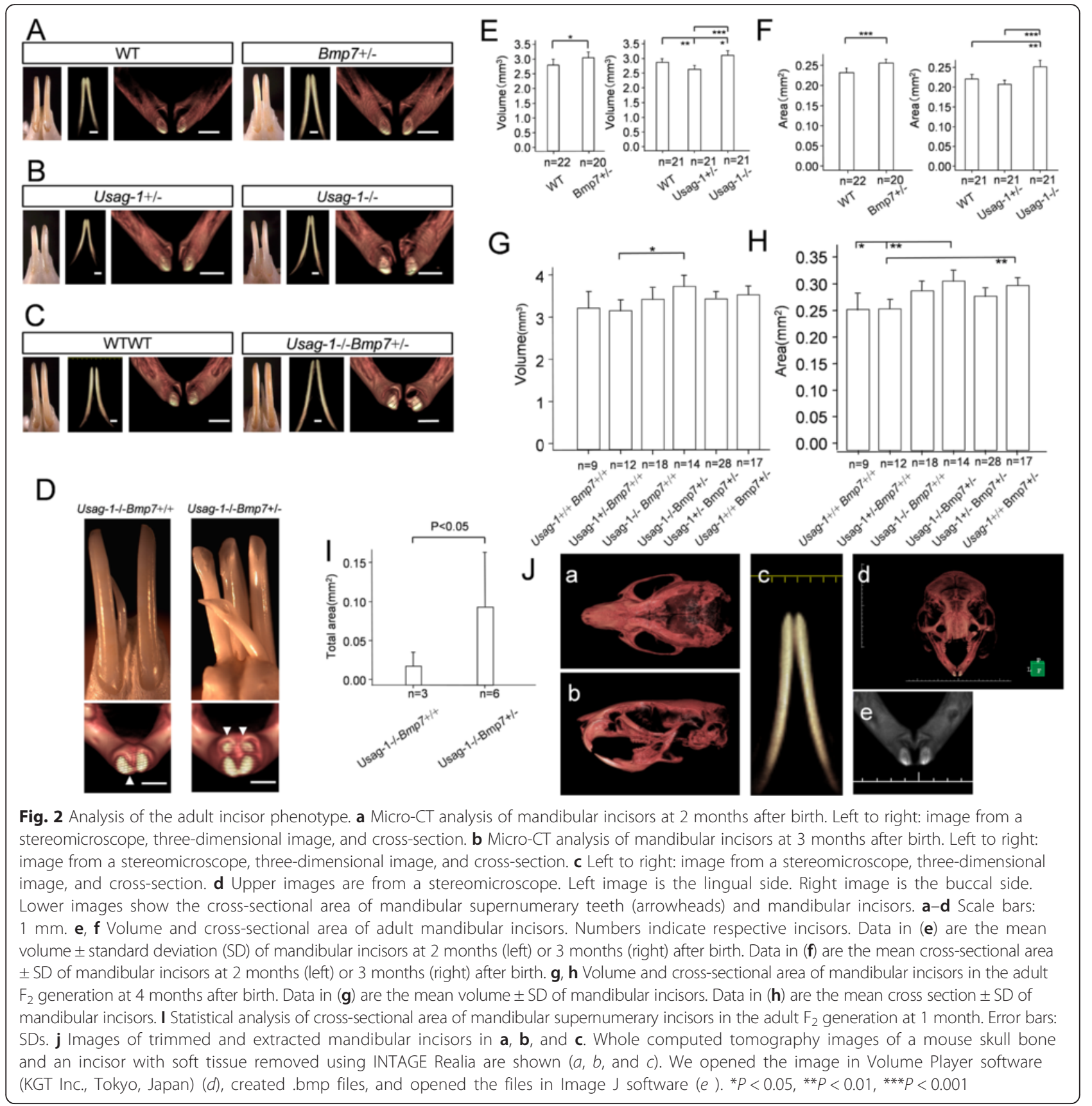

cap stage and early bell stage are considered equal to the morphogenetic phase. During the early bell stage, only the labial epithelium gives rise to the enamelforming ameloblasts in mandibular incisors [34]. Murine incisors are continuously growing; however, $B m p 7$ and Usag-1 are not expressed in enamel epithelial stem cells in adult mice [35].

Therefore, we investigated cell proliferation by BrdU staining in the mandibular incisors at E15, during the early bell stage. The tissues of the mandibular incisors at the early bell stage were categorized as vestibular lamina, stellate reticulum, dental papilla, labial mesenchyme, lingual mesenchyme, labial cervical loop, and lingual cervical loop (Fig. 4a, b). The labeling index of Bmp7+/- embryos was significantly higher than that of WT embryos in the cervical loop (Fig. 4c-f, j). Additionally, the labeling index of Usag-1-/- embryos was significantly higher than that of WT and Usag-1+/- embryos in dental papilla (Fig. 4g-i, k). The labeling index of WT embryos was significantly higher than that of Usag-1+/- embryos in stellate reticulum (Fig. 4k). 
A Usag-1+/+Bmp7+/+

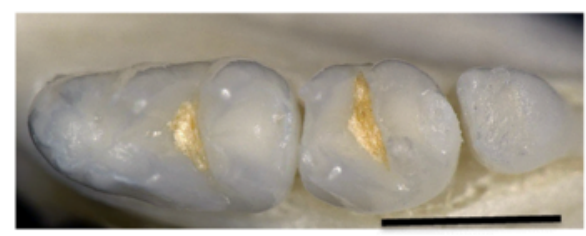

Usag-1+/-Bmp7+/+

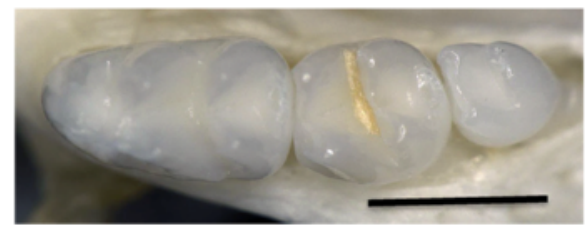

B

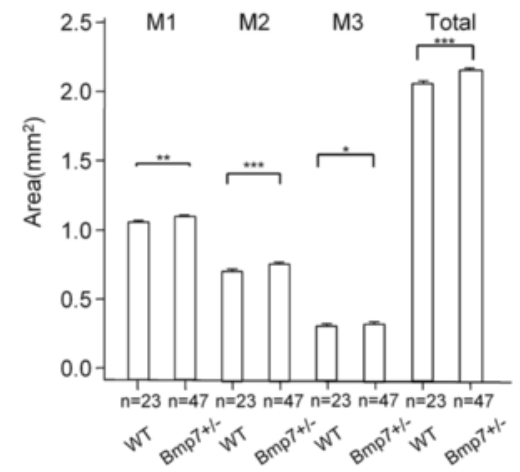

Usag-1+/+ Bmp7+/-

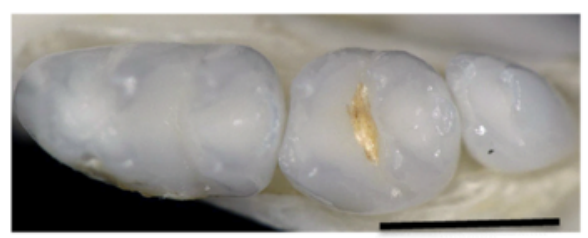

Usag-1+/-Bmp7+/-

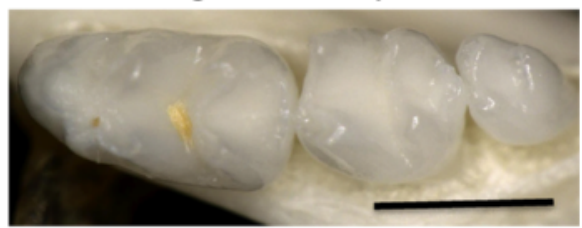

C

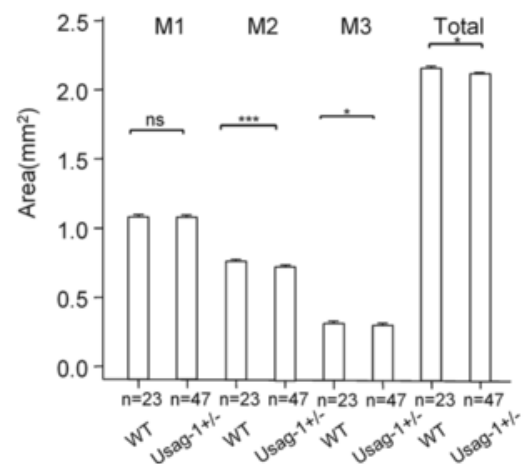

Fig. 3 Analysis of the adult molar phenotype. a Occlusal surface of mandibular molars in the $F_{2}$ generation at 1 month after birth. Scale bar indicates $1 \mathrm{~mm}$. b, c Statistical analysis of projected areas of the occlusal surface of three molars and all mandibular molars of the $F_{2}$ generation at 1 month after birth. ns: not significant, ${ }^{*} P<0.05$, ${ }^{* *} P<0.01$, ${ }^{* *} P<0.001$. b Mean area \pm standard deviation (SD) of mandibular molars in WT $(n=23)$ and Bmp7+/- $(n=47)$ mice. c Mean area \pm standard deviation (SD) of mandibular molars in WT $(n=23)$ and Usag-1+/$(n=47)$ mice

\section{TUNEL staining in the mandibular incisors at E15}

Next, we investigated the occurrence of apoptosis in cells in the mandibular incisors of $B m p 7+/-$ (ICR), Usag-1-/- (C57BL/6), Usag-1-/-Bmp7+/- $\left(\mathrm{F}_{2}\right.$ generation), and Usag-1+/- (C57BL/6) embryos at E15 (Fig. 4l). Apoptotic cells were detected near Meckel's cartilage, the developing bone and cartilage, the epithelium near the oral cavity, and the mesenchyme near the tooth germ (Fig. 4l). Few apoptotic cells were observed in the tooth germ for all genotypes. In the early bell stage, apoptosis was not associated with the determination of tooth size.

Table 1 A generalized linear model to analyze adult tooth size. The response variable is the total area of the occlusal surface of the molars of the $F_{2}$ generation at 1 month after birth

\begin{tabular}{lrrrr}
\hline & Estimate & Std.Error & T value & $P$ value \\
\hline Usag-1+/- & -0.05311 & 0.02503 & -2.122 & 0.03755 \\
Bmp7+/- & 0.09814 & 0.02503 & 3.921 & 0.00021 \\
\hline
\end{tabular}

\section{Analyzing mandibular supernumerary incisors in the} adult $F_{2}$ generation

In the $\mathrm{F}_{2}$ generation, the size of supernumerary incisors of Usag-1-/-Bmp7+/- mice was larger than that of Usag-1-/-Bmp7+/+ mice (Fig. 2d). Moreover, the total area of mandibular supernumerary incisors of Usag-1 $-/-B m p 7+/-$ mice was significantly larger than that of Usag-1-/-Bmp7+/+ mice (Fig. 2i).

\section{Discussion}

The expression levels of Usag-1 and Bmp7 are opposing in the region near the rudimentary incisor tooth primordia between the maxilla and mandible [28]. Moreover, in several types of genetically modified mice, the dental phenotype differs between the maxilla and mandible [13, 36, 37]. For example, in Usag-1-deficient mice, supernumerary teeth are observed in $100 \%$ of the maxillary incisor regions, whereas partial penetrance is observed in the mandible [26]. Thus, the genetic controls for tooth organ size and shape play critical roles in 
Table 2 A generalized linear model to analyze adult tooth size. The response variables are volume and cross-section of the mandibular incisors of the $F_{2}$ generation at 4 months after birth

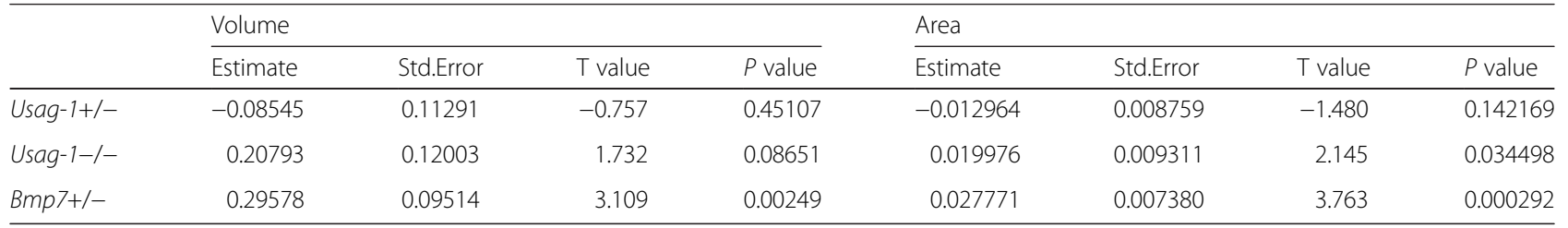

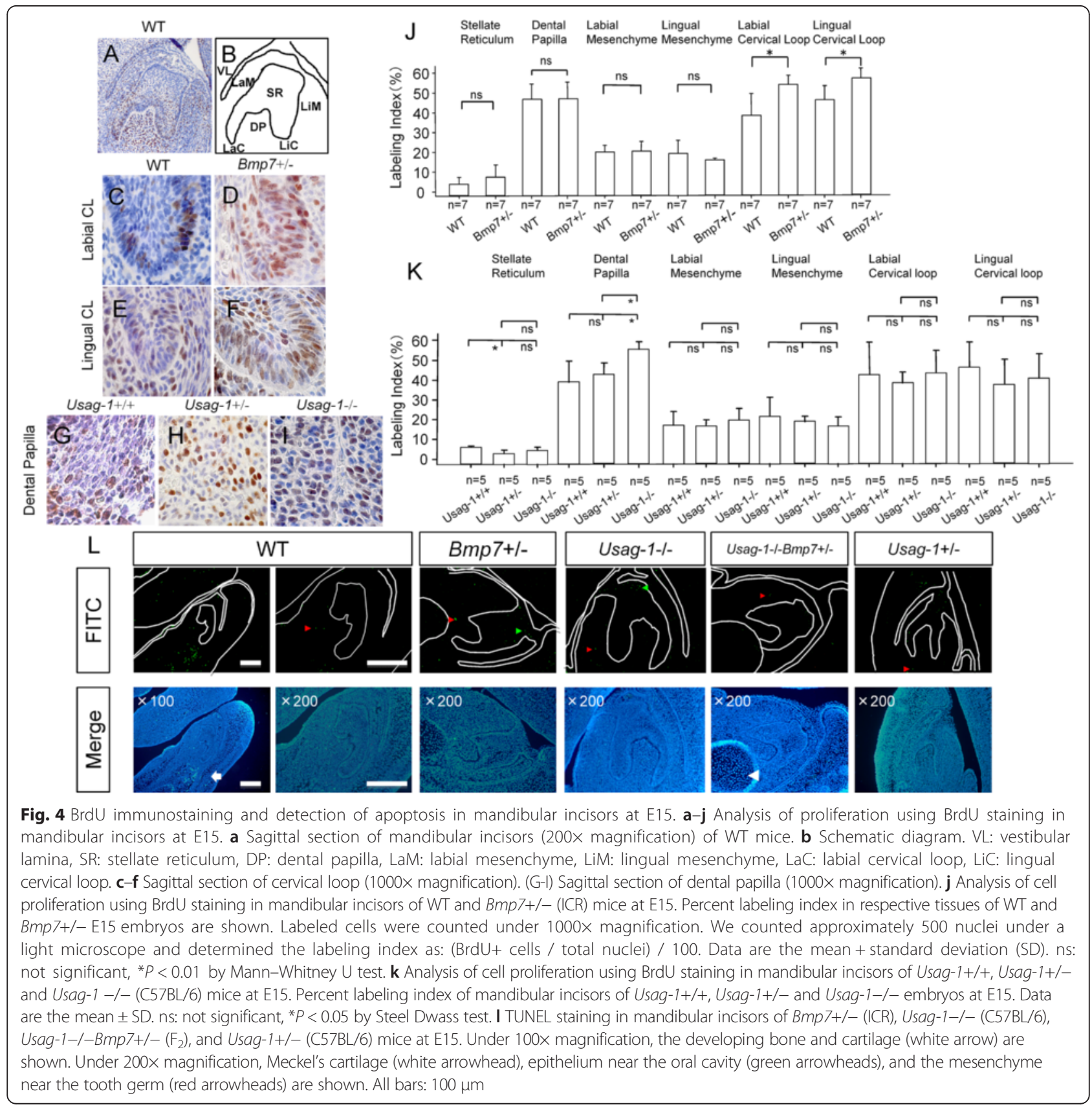


tooth regeneration. In this report, we demonstrated that the sizes of mandibular incisor and molar tooth organs in Bmp7+/- mice were significantly larger than those of WT mice. In contrast, the sizes of incisors and molars were significantly smaller in Usag-1+/- mice than in WT mice, and the volume and cross-sectional areas in Usag-1-/-, mice were significantly larger than those of all other genotypes. Thus, our results demonstrated, for the first time, that $B m p 7$ and Usag-1 heterozygous mice exhibited changes in tooth size.

In conditional Bmp7-deficient embryos, the maxillary incisors have been shown to be missing or hypoplastic [17]. Thus, the phenotypes of Usag-1 heterozygous mice and $B m p 7$ heterozygous mice were opposite those of Usag-1-deficient mice and Bmp7-deficient mice, respectively. Our results suggested that the levels of $B m p 7$ and Usag-1 expression in heterozygotes did not reach the threshold level necessary for normal tooth morphogenesis, that is, the embryos exhibited haploinsufficiency. Furthermore, heterozygotes may exhibit changes in downstream gene expression, resulting in changes in tooth size. Global analysis of gene expression in heterozygotes, such as microarray analysis and next-generation sequencing, is needed in order to elucidate the molecular mechanism involved in these processes.

The expression level of $B m p 7$ was similar to those of Wnt5a and Mrfzb1 and was localized adjacent to Usag-1 expression in the dental mesenchyme. USAG-1 is a BMP7 antagonist; however, the effects of BMP7 and USAG-1 were additive within the mandibular incisors of the $\mathrm{F}_{2}$ generation. BrdU assays confirmed that cell proliferation was increased within the cervical loop in association with larger sized mandibular incisors in $B m p 7+/-$ embryos. Furthermore, we confirmed that the increased cell proliferation of dental papilla mesenchymal cells was associated with larger mandibular incisors in Usag-1-/embryos. Importantly, apoptosis was not associated with tooth size at E15. These data indicated that there was a difference in the mechanisms of action of BMP7 and USAG-1 during the cap or bell stages of tooth morphogenesis. Continuous growth and enamel deposition in incisors can be modulated by the levels of FGF3/10, activin, and BMP2/4/7 mesenchymally expressed in the epithelial stem cell niche [38]. Thus, we concluded that elongation of the cervical loop in $B m p 7+/-$ embryos at E15 enlarged the incisors and that BMP7 expressed in the mesenchyme around the cervical loop had distinct local effects on the loop.

The volume and cross-sectional area were largest in Usag-1-/- mice, and the labeling index of the dental papilla in Usag-1-/ - mice was highest of all genotypes examined. We have also reported that phosphorylated SMAD1/5/8 levels are increased and that $\beta$-catenin is localized in the nucleus in odontogenic mesenchymal cells within the maxillary rudimentary incisor tooth organ in Usag-1-deficient embryos [27]. Using organ culture of WT and Usag-1-deficient mandibular incisors, Munne et al. demonstrated that Usag-1 expression is limited to the mesenchyme and that the dental mesenchyme may limit supernumerary tooth induction resulting from activated Wnt signaling, thereby minimizing the amount of mesenchymal tissue surrounding the incisor tooth germs prior to culture [39]. USAG-1 is downstream of sonic hedgehog (Shh) signaling; therefore, a Wnt-Shh-SOSTDC1 negative feedback loop may control the spatial patterning of teeth, and Wnt, Shh, and SOSTDC1 may act as the activator, mediator, and inhibitor, respectively, in reaction-diffusion models [32]. Consistent with this, patients with supernumerary teeth have larger teeth than controls in humans [40]. Thus, these findings, combined with our new results, suggest that enhanced Bmp- and Wnt-mediated signal transduction in the dental mesenchyme of Usag-1-/- mice may increase the proliferation of cells in the dental mesenchyme at the cap or early bell stages, resulting in increased tooth size and formation of supernumerary teeth.

The size of a tooth is determined not only by genes related to tooth development but also by the development of the mandible. The size of mandibular incisors is altered by craniosynostoss in the Apert Fgfr $2^{\mathrm{S} 252 \mathrm{~W}}$ mouse model [41]. Importantly, in our study, we found no significant difference in the linear distance of the anteroposterior diameter and altitude between respective genotypes in Bmp7-LacZ knock-in mice at 2 months of age (Additional file 3: Figure S3B). However, at 3 months of age, Usag-1-/- mice exhibited a significantly longer linear distance of the anteroposterior diameter and altitude compared with that in WT and Usag-1+/- mice (Additional file 3: Figure S3C). The development of the mandible in the context of Usag- 1 deficiency may be associated with changes in the size of the mandibular incisor and molar in Usag-1-/- mice. These results suggested that we may be able to control the size of teeth by regulating the gene expression level locally in humans when dental epithelial stem cells, such as third dentitions and outer enamel epithelium, are used for tooth regeneration in vivo.

\section{Conclusion}

Our findings showed that $B m p 7$ heterozygous mice exhibited dramatic increases in tooth size and that tooth size was controlled by the expression levels of specific genes.

\section{Ethics approval and consent to participate}

The study protocol and procedures were approved by the Animal Research Committee of Kyoto University (reference number: Med Kyo 11518) and the Recombinant 
DNA Experiment Safety Committee of Kyoto University. All experiments were carried out in accordance with the approved guidelines.

\section{Consent for publication Not applicable.}

\section{Additional files}

Additional file 1: Figure S1. $X$-gal staining in mandibular molars of Usag-1+/- (C57BL/6) mice at E14 and E15. Tissue sections from mandibular molars of Usag-1+/- (C57BL/6) mice at E14 and E15 were stained with X-gal. Scale bar: $100 \mu \mathrm{m}$. (A, B) Sagittal sections. (C) Coronal sections. (B, C) Usag-1 was expressed (blue) in a small portion of epithelia, except for the enamel knot and the mesenchyme near the tooth germ. (TIF $16106 \mathrm{~kb}$ )

Additional file 2: Figure S2. Malocclusion observed in Usag-1-/(C57BL/6) mice and Usag-1-/- Bmp7+/- ( $F_{2}$ generation) mice. (A) Normal occlusion. A Usag-1-/- female mouse in the C57BL/6 background at 3 months after birth. These data were added in the analysis of the lower incisors. Scale bar: $1 \mathrm{~mm}$. (B) Normal occlusion. A Usag-1-/ $-B m p 7+/-$ male mouse in the $F_{2}$ generation at 4 months after birth. These data were added in the analysis of the lower incisors. (C) Malocclusion. A Usag-1-/- female mouse in C57BL/6 background at 3 months after birth. The mouse was excluded from the analysis of the lower incisors. (D) Malocclusion. A Usag-1-/-Bmp7+/- female mouse in the $\mathrm{F}_{2}$ generation at 4 months after birth. The mouse was excluded from the analysis of the lower incisors. (TIF $14671 \mathrm{~kb}$ )

Additional file 3: Figure S3. Difference in mandibular morphology between respective genotypes in Bmp7 or Usag-1-LacZ knock-in mice. (A) Wild-type mouse (ICR) mandible at 2 months after birth with locations of landmarks used to analyze the morphological differences between respective genotypes. Linear distances between the identifiable landmarks were measured. a: inferior-most point on the incisor alveolar rim, b: anterior point on the molar alveolar rim, c: inferior-most point on border of the ramus inferior to incisor alveolar, d: mandibular angle. (B) Difference in mandibular morphology between WT and $B m p 7+/-$ mice. We analyzed a total of $6 \mathrm{WT}$ and $6 \mathrm{Bmp7+/-} \mathrm{samples} \mathrm{in} \mathrm{adult} \mathrm{Bmp7-LacZ} \mathrm{knock-in} \mathrm{(ICR)}$ mice at 2 months after birth. Statistical significance was determined by the Mann-Whitney $\mathrm{U}$ test. (C) Difference in the mandibular morphology among WT, Usag-1+/-, and Usag-1-/- mice. We analyzed a total of 6 individual genotypes in adult Usag1-LacZ knock-in (C57BL/6) mice at 3 months after birth. Statistical significance was determined using a Kruskal-Wallis test and a Steel-Dwass test for multiple comparisons. ${ }^{*} P<0.05$. (TIF $3530 \mathrm{~kb}$ )

\section{Abbreviations}

-/-: Knockout genotype; +/-: Heterozygous genotype; +/+: Wild-type; LacZ/ LacZ: Knockout genotype in LacZ knock-in mice; WT: Wild-type.

\section{Competing interests}

The authors declare that they have no competing interests.

\section{Authors' contributions}

$\mathrm{KS}, \mathrm{KT}, \mathrm{KB}, \mathrm{MA}$, and $\mathrm{MM}$ contributed to the conception and design of the experiment. $\mathrm{KS}, H K, Y T$, and $H T$ contributed to acquisition of the data. MA carried out measurement and analysis of the molars. KS drafted the manuscript. $K T, M A, B H, H C S, M S$, and AS revised the manuscript. All authors reviewed the manuscript. All authors read and approved the final manuscript.

\section{Acknowledgments}

Bmp7-LacZ knock-in mice were a kind gift from Dr. Elizabeth Robertson of Oxford University. The authors are indebted to Dr. Motoko Yanagita of Kyoto University for helpful discussions. Usag-1-LacZ knock-in mice were a kind gift from Aris N. Economides of Regeneron Pharmaceuticals Inc. in Tarrytown, New York, USA.

\section{Funding}

This study was supported by a Grant-in-Aid for Scientific Research (C) from the Japanese Society for the Promotion of Science.

\section{Author details}

'Department of Oral and Maxillofacial Surgery, Graduate School of Medicine, Kyoto University, Shogoin-Kawahara-cho 54, Sakyo-ku, Kyoto 606-8397, Japan ${ }^{2}$ College of Liberal Arts and Sciences, Mie University, Mie, Japan. ${ }^{3}$ School of Dentistry and Health Sciences, Sturt University, Orange, Australia. ${ }^{4}$ Department of Molecular Genetics, Division of Medicine, Faculty of Medical Sciences, University of Fukui, Fukui, Japan. ${ }^{5}$ Department of Experimental Therapeutics, Institute for Advancement of Clinical and Translational Science, Kyoto University Hospital, Kyoto, Japan. ${ }^{6}$ Kyoto University Museum, Kyoto University, Kyoto, Japan. ${ }^{7}$ Center for Craniofacial Molecular Biology, Division of Biomedical Sciences, Ostrow School of Dentistry, University of Southern California, Los Angeles, CA, USA.

Received: 6 January 2016 Accepted: 9 May 2016

Published online: 13 May 2016

\section{References}

1. Chai Y, Slavkin HC. Prospects for tooth regeneration in the 21st century: a perspective. Microsc Res Tech. 2003;60(5):469-79.

2. Koch WE. In vitro differentiation of tooth rudiments of embryonic mice. I. Transfilter interaction of embryonic incisor tissues. J Exp Zool. 1967;165(2): $155-70$.

3. Kollar EJ, Baird GR. The influence of the dental papilla on the development of tooth shape in embryonic mouse tooth germs. J Embryol Exp Morphol. 1969;21(1):131-48

4. Thesleff I, Sharpe P. Signalling networks regulating dental development. Mech Dev. 1997;67(2):111-23.

5. Thesleff I, Vaahtokari A, Partanen AM. Regulation of organogenesis. Common molecular mechanisms regulating the development of teeth and other organs. Int J Dev Biol. 1995;39(1):35-50.

6. Cai J, Mutoh N, Shin JO, Tani-Ishii N, Ohshima H, Cho SW, Jung HS. Wnt5a plays a crucial role in determining tooth size during murine tooth development. Cell Tissue Res. 2011;345(3):367-77.

7. Lin M, Li L, Liu C, Liu H, He F, Yan F, Zhang Y, Chen Y. Wnt5a regulates growth, patterning, and odontoblast differentiation of developing mouse tooth. Dev Dyn. 2011;240(2):432-40.

8. Sarkar L, Sharpe PT. Inhibition of Wnt signaling by exogenous Mfrzb1 protein affects molar tooth size. J Dent Res. 2000;79(4):920-5.

9. Tucker AS, Matthews KL, Sharpe PT. Transformation of tooth type induced by inhibition of BMP signaling. Science. 1998;282(5391):1136-8.

10. Cai J, Cho SW, Kim JY, Lee MJ, Cha YG, Jung HS. Patterning the size and number of tooth and its cusps. Dev Biol. 2007;304(2):499-507.

11. Chen J, Lan Y, Baek JA, Gao Y, Jiang R. Wnt/beta-catenin signaling plays an essential role in activation of odontogenic mesenchyme during early tooth development. Dev Biol. 2009;334(1):174-85.

12. Ferguson CA, Tucker AS, Christensen L, Lau AL, Matzuk MM, Sharpe PT. Activin is an essential early mesenchymal signal in tooth development that is required for patterning of the murine dentition. Genes Dev. 1998;12(16):2636-49.

13. Fujimori S, Novak $H$, Weissenbock M, Jussila M, Goncalves A, Zeller R, Galloway J, Thesleff I, Hartmann C. Wnt/beta-catenin signaling in the dental mesenchyme regulates incisor development by regulating Bmp4. Dev Biol. 2010;348(1):97-106.

14. Kettunen P, Laurikkala J, Itaranta P, Vainio S, Itoh N, Thesleff I. Associations of FGF-3 and FGF-10 with signaling networks regulating tooth morphogenesis. Dev Dyn. 2000:219(3):322-32.

15. Vainio S, Karavanova I, Jowett A, Thesleff I. Identification of BMP-4 as a signal mediating secondary induction between epithelial and mesenchymal tissues during early tooth development. Cell. 1993;75(1):45-58.

16. Ishida K, Murofushi M, Nakao K, Morita R, Ogawa M, Tsuji T. The regulation of tooth morphogenesis is associated with epithelial cell proliferation and the expression of Sonic hedgehog through epithelial-mesenchymal interactions. Biochem Biophys Res Commun. 2011;405(3):455-61.

17. Zouvelou V, Luder HU, Mitsiadis TA, Graf D. Deletion of BMP7 affects the development of bones, teeth, and other ectodermal appendages of the orofacial complex. J Exp Zool B Mol Dev Evol. 2009;312B(4):361-74.

18. Hassel S, Schmitt S, Hartung A, Roth M, Nohe A, Petersen N, Ehrlich M, Henis YI, Sebald W, Knaus P. Initiation of Smad-dependent and Smad- 
independent signaling via distinct BMP-receptor complexes. J Bone Joint Surg Am. 2003:85-A Suppl 3:44-51.

19. Shibuya H, Iwata H, Masuyama N, Gotoh Y, Yamaguchi K, Irie K, Matsumoto $K$, Nishida $E$, Ueno $N$. Role of TAK1 and TAB1 in BMP signaling in early Xenopus development. EMBO J. 1998;17(4):1019-28.

20. Sugimori K, Matsui K, Motomura H, Tokoro T, Wang J, Higa S, Kimura T, Kitajima I. BMP-2 prevents apoptosis of the N1511 chondrocytic cell line through PI3K/Akt-mediated NF-kappaB activation. J Bone Miner Metab. 2005;23(6):411-9.

21. Yamaguchi K, Nagai S, Ninomiya-Tsuji I, Nishita M, Tamai K, Irie K, Ueno N, Nishida E, Shibuya H, Matsumoto K. XIAP, a cellular member of the inhibitor of apoptosis protein family, links the receptors to TAB1-TAK1 in the BMP signaling pathway. EMBO J. 1999;18(1):179-87.

22. Itasaki N, Jones CM, Mercurio S, Rowe A, Domingos PM, Smith JC, Krumlauf R. Wise, a context-dependent activator and inhibitor of Wnt signalling. Development. 2003;130(18):4295-305.

23. Lintern KB, Guidato S, Rowe A, Saldanha JW, Itasaki N. Characterization of wise protein and its molecular mechanism to interact with both Wnt and BMP signals. J Biol Chem. 2009;284(34):23159-68.

24. Ohazama A, Johnson EB, Ota MS, Choi HY, Porntaveetus T, Oommen S, Itoh N, Eto K, Gritli-Linde A, Herz I et al. Lrp4 modulates extracellular integration of cell signaling pathways in development. PLoS One. 2008;3(12):e4092.

25. Yanagita M, Oka M, Watabe T, Iguchi H, Niida A, Takahashi S, Akiyama T, Miyazono K, Yanagisawa M, Sakurai T. USAG-1: a bone morphogenetic protein antagonist abundantly expressed in the kidney. Biochem Biophys Res Commun. 2004;316(2):490-500.

26. Murashima-Suginami A, Takahashi K, Kawabata T, Sakata T, Tsukamoto H, Sugai M, Yanagita M, Shimizu A, Sakurai T, Slavkin HC et al. Rudiment incisors survive and erupt as supernumerary teeth as a result of USAG-1 abrogation. Biochem Biophys Res Commun. 2007;359(3):549-55.

27. Murashima-Suginami A, Takahashi K, Sakata T, Tsukamoto H, Sugai M, Yanagita M, Shimizu A, Sakurai T, Slavkin HC, Bessho K. Enhanced BMP signaling results in supernumerary tooth formation in USAG-1 deficient mouse. Biochem Biophys Res Commun. 2008;369(4):1012-6.

28. Kiso H, Takahashi K, Saito K, Togo Y, Tsukamoto H, Huang B, Sugai M, Shimizu A, Tabata Y, Economides AN et al. Interactions between BMP-7 and USAG-1 (uterine sensitization-associated gene-1) regulate supernumerary organ formations. PLoS One. 2014;9(5):e96938.

29. Godin RE, Takaesu NT, Robertson EJ, Dudley AT. Regulation of BMP7 expression during kidney development. Development. 1998;125(17):3473-82.

30. Tanaka M, Endo S, Okuda T, Economides AN, Valenzuela DM, Murphy AJ, Robertson E, Sakurai T, Fukatsu A, Yancopoulos GD et al. Expression of BMP7 and USAG-1 (a BMP antagonist) in kidney development and injury. Kidney Int. 2008;73(2):181-91.

31. Ito H, Matsuno T, Hirayama T, Tanino H, Yamanaka Y, Minami A. Threedimensional computed tomography analysis of non-osteoarthritic adult acetabular dysplasia. Skeletal Radiol. 2009;38(2):131-9.

32. Cho SW, Kwak S, Woolley TE, Lee MJ, Kim EJ, Baker RE, Kim HJ, Shin JS, Tickle C, Maini PK et al. Interactions between Shh, Sostdcl and Wnt signaling and a new feedback loop for spatial patterning of the teeth. Development. 2011;138(9):1807-16.

33. Kassai Y, Munne P, Hotta Y, Penttila E, Kavanagh K, Ohbayashi N, Takada S, Thesleff I, Jernvall J, Itoh N. Regulation of mammalian tooth cusp patterning by ectodin. Science. 2005;309(5743):2067-70.

34. Harada H, Toyono T, Toyoshima K, Yamasaki M, Itoh N, Kato S, Sekine K, Ohuchi H. FGF10 maintains stem cell compartment in developing mouse incisors. Development. 2002;129(6):1533-41.

35. Kuang-Hsien Hu J, Mushegyan V, Klein OD. On the cutting edge of organ renewal: Identification, regulation, and evolution of incisor stem cells. Genesis. 2014;52(2):79-92.

36. Klein OD, Minowada G, Peterkova R, Kangas A, Yu BD, Lesot H, Peterka M, Jernvall J, Martin GR. Sprouty genes control diastema tooth development via bidirectional antagonism of epithelial-mesenchymal FGF signaling. Dev Cell. 2006;11(2):181-90.

37. Peterkova R, Lesot $H$, Viriot L, Peterka M. The supernumerary cheek tooth in tabby/EDA mice-a reminiscence of the premolar in mouse ancestors. Arch Oral Biol. 2005;50(2):219-25.

38. Wang XP, Suomalainen M, Felszeghy S, Zelarayan LC, Alonso MT, Plikus MV, Maas RL, Chuong CM, Schimmang T, Thesleff I. An integrated gene regulatory network controls stem cell proliferation in teeth. PLoS Biol. 2007;5(6):e159.
39. Munne PM, Tummers M, Jarvinen E, Thesleff I, Jernvall J. Tinkering with the inductive mesenchyme: Sostdc1 uncovers the role of dental mesenchyme in limiting tooth induction. Development. 2009;136(3):393-402.

40. Brook AH, Griffin RC, Smith RN, Townsend GC, Kaur G, Davis GR, Fearne J. Tooth size patterns in patients with hypodontia and supernumerary teeth. Arch Oral Biol. 2009;54 Suppl 1:563-70.

41. Holmes G, Basilico C. Mesodermal expression of Fgfr2S252W is necessary and sufficient to induce craniosynostosis in a mouse model of Apert syndrome. Dev Biol. 2012;368(2):283-93.

\section{Submit your next manuscript to BioMed Central and we will help you at every step:}

- We accept pre-submission inquiries

- Our selector tool helps you to find the most relevant journal

- We provide round the clock customer support

- Convenient online submission

- Thorough peer review

- Inclusion in PubMed and all major indexing services

- Maximum visibility for your research

Submit your manuscript at www.biomedcentral.com/submit
( ) BioMed Central 